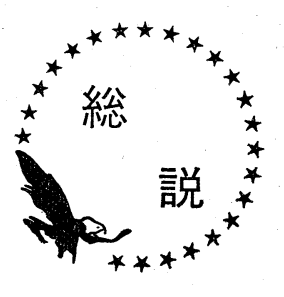

は じめに

昭和 45 年 7 月，運輸大臣の諮問機関である運輸審議 会自動車部会は，わが国の自動車排出ガス対策基本計 画をまとめ運輸大臣に答申した。これは従来より規制 の対象であつた $\mathrm{CO}$ の他に, 炭化水素, $\mathrm{NO}_{x}$, 微粓子な ども含むものであり, 昭和 45 年 3 月, HEW が発表し たアメリカの長期低減計画とほぼ同レベルの規制目標 值で, 現在の技術では達成するのが困難と思われるほ ど厳しいものである。一方これに対応して通産大臣の 諮問機関である産業構造審議会産業公害部自動車公害 対策小委員会は，45年 8 月，50年の自動車排出ガス低 減目標を達成するための自動車排出ガス対策の方向つ けとその推進方法について中間答申を行なつた。これ はエンジンの改造および排出ガス浄化装置の開発，カ ソリンの無鉛化，新動刀源車の開発を骨子とするもの である。ここにはじめて，わが国の自動車ガソリンの 無鉛化が方向づけられたわけである。

\section{表 1 わが国の自動車排出ガスの規制案}

（運輸技術審議会の中間報告）

$\mathrm{CO}$ 昭和 48 年 4 月 昭和 50 年 4 月

炭化水素 $11 \mathrm{~g} / \mathrm{km}$ 以下 $7 \mathrm{~g} / \mathrm{km}$ 以下

$\mathrm{NO}_{x}$ $1.7 \mathrm{~g} / \mathrm{km}$ 以下 $0.3 \mathrm{~g} / \mathrm{km}$ 以下 燃料蒸発量 $6 \mathrm{~g} /$ 日以下 $3 \mathrm{~g} / \mathrm{km}$ 以下 $0.6 \mathrm{~g} / \mathrm{km}$ 以下

排気ガス中の微粒子

ガソリンの無鉛化は製造上，また使用上いろいろな 問題をなげかけることになる。まず製造上の問題とし ては，品質設計の問題，ガソリン組成の規制の問題， ガソリン製造装置選定の問題，無鈶化のコストアップ の問題などであり，使用上の問題としては，無鉛化が スタートする昭和 49 年に 1,000 万台以上も走行してい ると予想される未対策車のバルブシートリセッション や充足率の低下，すなわちノッキングの発生の問題な ぞである。そこで本稿ではこれらの問題点について概 括的に考察することにする。
丸善石油株式会社 内 田 三 一 郎

\section{1 無鉛ガソリン製造上の問題点}

1-1 無鉛ガソリンの品質設計

産構審の答申では，無鉛ガソリンのリサーチ法オク タン価は, レギュラ一級88以上，プレミアム級 95 以上 となつているものの, 無鉛化の時点で, はたしてどの ような品質が要求されるか，いまのところ明らかでは ない。しかし，本質的に無鉛ガソリンになつても適正 な揮発性 (分留特性) と全沸点範囲にわたつて，高い オクタン価が要求されることはいうまでもない，レギ ユラ一級ガソリンについては比較的その影響は小さい が，プレミアム級ガソリンの品質設計に際してはさま ざまな問題を提起さすことになる。表 2 はわが国とア メリカにおける主要高オクタン価ガソリン製造装置の 常圧蒸留装置に対する能力比率を表示したものであ る。

\section{表 2 ガソリン製造装置の対原油処理能力比率} (単位:\%)

$\begin{array}{lrc} & \text { 日本 } & \text { アメリカ } \\ \text { 改 質 装 置 } & 10.8 & 21.9 \\ \text { 接触分解装置 } & 4.9 & 46.3 \\ \text { 水素化分解装置 } & 0 & 4.8 \\ \text { アルキル化装置 } & 0.04 & 5.9\end{array}$

わが国の場合，改質ガソリンが，ガソリン基材の大 半を占め, つづいて接触分解ガソリン, 直留ガソリン が使われている。図 1 は改質ガソリンの沸点範囲と, リサーチ法オクタン価の関係を表示したものである。 改質ガソリンは, 高沸点留分のリサーチ法オクタン価 は非常に高いが，低沸点留分のオクタン価は低く, 低 沸点留分が少ないことが特長である。この傾向は無鉛 化に伴つて，改質ガソリンのオクタン価がより高くな ると考えられるので，ますます助長されるであろう。 加鉛ガソリンの場合，この欠点は改質ガソリンの配合 割合や，加鉛量を調整することによつて補われてきた が，いうまでもなく無鉛の場合，加鉛による調整は不 可能になる。接触分解ガソリンは図 2 に表示するよう 


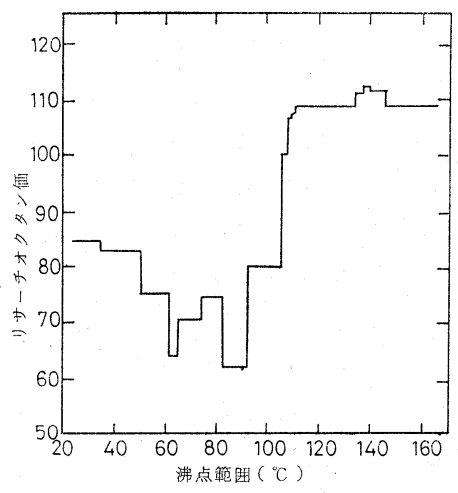

図 1 改質ガソリン (95RON無鉛) のオクタン 価特性

Oil \& Gas J., 57, No.8, Feb16, p.105 (1959)

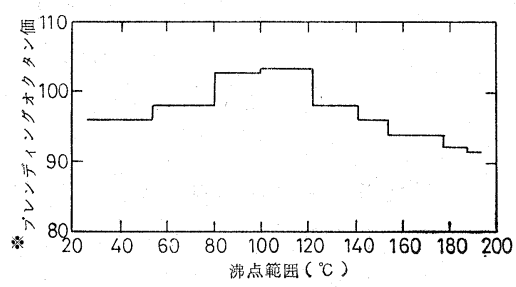

* 改質カツリンとブレンディングオクタン価

図 2 FCCガソリン (93RON無鉛) のオクタ ン価特性

丸善石油商品研究所データ

に，改質ガソリンとは逆に，低沸点留分のリサーチ法 オクタン価が高いという特性を持つている。反面，才 レフィン含有量が高く, 高速域のアンチノック性に関 係のあるモーター法オクタン価がそれに比べて低いと いう欠点がある。そこで今後無鉛ガソリンの品質設計 に際して，まず問題になるのが，リサーチ法オクタン 価 (RON), モーター法オクタン価 (MON), ディスト リビューション法オクタン価 (DON) で表わされるガ ソリンのアンチノック性の問題と, 揮発性の問題であ る。

無鉛ガソリンを使用すると，その使用開始時点では 車のオクタン価要求值は加鉛ガソリンとほとんど差は ないが, ある程度の走行距離に達すると, オクタン価 要求值は, 加鉛ガソリンを使用した場合より增加する といわれている。その原因は無鉛化に伴つて, ガソリ ン中の芳香族が増加することになり，长の結果，エン ジン室内により多くのデポジットが生成されるからで

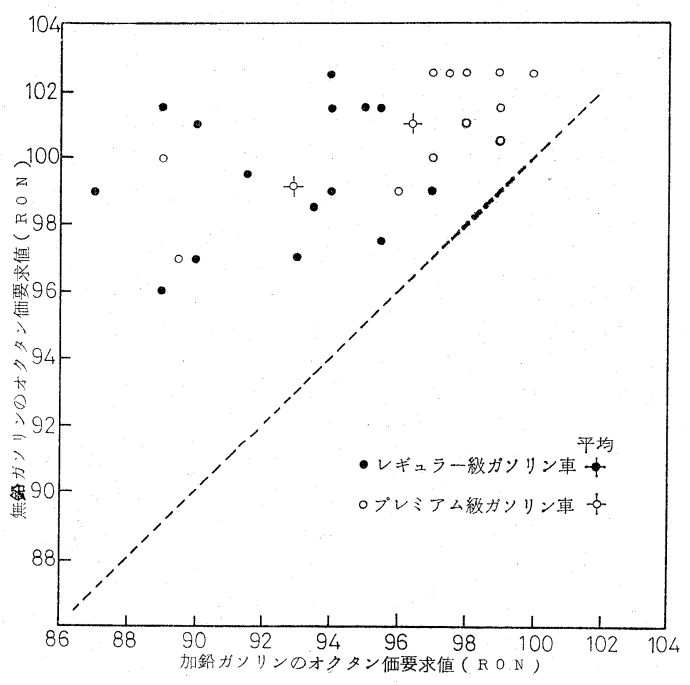

図 3 無鉛ガソリンと加鉛ガソリンのオクタン 価要求值の比較

（スロットル弁全開時）

あると考えられている23344)5)。図3 はスロットル弁全 開時での加鉛ガソリンと無鉛ガソリンのオクタン価要 求值の比較を示したものである。この図は低オクタン 価の領域でその差が大きく，プレミアム級ガソリン使 用車の場合で，平均 4. $6 \mathrm{RON}$ レギュラー級ガソリン使 用車の場合で，平均 6.3RONも差があることを示して いる。CRCが71年型車について同様の実験を行ない, その差は 0.6 RONであると報告している。アメリカの ある大手石油会社もエチル社に近い結果を得ているこ とから推定すれば, オクタン価要求值のいくらかの上 昇は避けられないであろう。これは無鉛化時におい て，改質ガソリンのウエイトがますと思われる。わが 国にとつて，重要な問題となろう。いずれにせよ，自 動車メーカーは, いくらか割引いたオクタン価を基準 にエンジン設計をする必要があり，一方石油精製会社 としては，加鉛ガソリンの場合より若干オクタン価の 高いガソリンを考える必要があろう。

さて，わが国の場合リサーチオクタン価は満足しえ たとしても，加鉛ガソリンの場合と同じょうなセンシ ティビティーを維持することは容易なことではない。 いうまでもなく，センシティビティーは，リサーチ法 オクタン価とモーター法オクタン価との差と定義され る。モーター法オクタン価はリサーチ法より苛酷な条 件下で測定されるオクタン価なので，高速域での走行 オクタン価と関係がある。したがつて近年高速道路の 発達につれて, 高速, 高負荷運転の機会が多くなつて 
きており，加えて自動変速機車の普及などの理由で, リサーチ法オクタン価よりモーター法オクタン価を重 視す心゙きであるという意見が多くなつてきている ${ }^{3) 6) 。 ~}$ 無鉛化に伴い，リサーチ法オクタン価が低下すること になるので，無鉛カソリン車は，低圧縮比で設計さ れ，したがつてリサーチ法オクタン価要求值は低下す るものと予想されるが，はたしてモーター法オクタン 価についてはどうなるか予想が難しい。表 3 は東京地

\section{表 3 わが国における市販ガソリンの性状*}

\begin{tabular}{|c|c|c|}
\hline 比 重 & 0.7644 & 0.7432 \\
\hline 分留10\% ${ }^{\circ} \mathrm{C}$ & 53.0 & 51.5 \\
\hline (エングラー) $50 \%$ & 109.0 & 96.5 \\
\hline $90 \%$ & 159.5 & 159.0 \\
\hline 蒸気压 $\mathrm{kg} / \mathrm{cm}^{2}$ & 0.61 & 0.60 \\
\hline オレフィン vol\% & 4.0 & 7.0 \\
\hline 芳香族 & 42.5 & 30.0 \\
\hline 飽 和 & 53.5 & 63.0 \\
\hline 加鉛量 $\mathrm{Pb} \cdot \mathrm{gr} / l$ & 0.23 & 0.100 \\
\hline オクタン価(F-1) & 97.4 & 90.4 \\
\hline$(F-2)$ & 87.8 & 82.1 \\
\hline センシティビティー & 9.6 & 8.3 \\
\hline DON & 95.4 & 87.8 \\
\hline
\end{tabular}

区で行なつた市販ガソリンの品質調查に基づく，わが 国市販ガソリンの単純平均性状である。プレミアム級 およびレギュラー級ガソリンの平均モーター法オク夕
ン価は，それぞれ，87.8MON，82.1MONでセンシテ イビティーはそれぞれ9.6，8.3である。一方アメリカ の場合，昭和45年の代表的プレミアム級，レギュラー 級ガソリンのセンシティビティーはそれぞれ $8.5,8.4$ と推定される7)。表 4 は, 石油供給計画に基づいて推 定したわが国におけるガソリンの単純平均ガソリン配 合率と, 昭和45年のアメリカにおける代表的なガソリ ン配合割合を示したものである7)。基準が異なるので 単純には比較できないが，センシティビティーはわが 国の方がレギュラー級ガソリンで 0.8 , プレミアム級 ガソリンで 1.3 大きい。しかし無鉛で比較した場合, レギュラー級ガソリンについてはほぼ等しく，プレミ アム級ガソリンについては1.5 程度わが国の方が大き いと推定される。さて無鉛ガソリンを製造する場合, 一般には改質ガソリンのウェイトを高める必要が生 じ，それは配合率をあげるか，才クタン価のより高い 改質ガソリンを配合するかのどちらかである。したが つて直留ガソリンと改質ガソリンで, 無鈶プレミアム 級ガソリンを製造しょうとすると，センシティビティ 一は大きくなる。そこで, モーター法オクタン価を所 定のレベルまで上げようとするならば，改質ガソリン の配合率を上げてリサーチ法オクタン価をさらに上げ る必要が生ずる。しかしこれはガソリンの揮発性の面 から，適正なガソリンを製造することを不可能なもの にするであろう。一方接触分解ガソリンと改質ガソリ ンによつて，プレミアム級ガソリンを製造する場合に は, 改質カソリンの増加によつて, 相対的にモーター 法オクタン価はわずかながら上昇する傾问にある。し 募しこれは反面，低速域でのアンチノック性と関係が あるディストリビューション法オクタン価 (DON)

表 4 日本およびアメリカにおけるガソリン配合比率（推定）

$\frac{\text { 日 }}{\text { プレミアム級ガソリ }} \frac{\text { レギュラー級ガソリ }}{\text { ソ* }}$

$\mathrm{C}_{4}$

改質ガソリン
接触分解ガソリン
アルキレート
直留ガソリン
水素化分解ガソリン
その 他

100
39.9

16.2

3.2

2.4

4.5

100.0

17.7

0.9

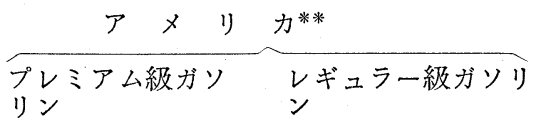

6.0

5.8

$18.0 \quad 41.9$

$48.0 \quad 28.2$

27.2

17.4

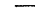

2.8

15.4

-

3.9

100.0

100.0

* 供給計画に基づく平均值

** 代表的なもの 
を下げる要因となる。近年わが国においても，中高速 域で最大オクタン価要求值を示す自動車か增加する傾 向にあるが, 依然として低速域で最大オクタン価要求 値を示す自動車が多いため，わが国においてはとくに ディストリビューション法オクタン価が重要視されて きた。もちろんこれは無鉿化時代においても，同様で あろう。したがつて,これらの関係を的確にとらえ， ガソリンの品質設計を行なうことが重要であるが，将 来どのような品質が要求されるか，現段階で予測する ことは困難な状態にある。いずれにしろ鉛が消え去る ことは，ガリリンの品質設計を困難なものにすること は明らかである。

1-2 ガソリン組成（芳香族およびオレフィン規制）

ガソリン中の芳香族やオレフィン合有量の規制が, まじめに議論され，一時大騒ざを起こしたことがあ る。当時, 規制派の理論的根拠に明確さを欠いたきら いがあつたが, (1)ガソリン中の芳香族やオレフィンが 多いほど，自動車やガソリンスタンドから排出される 有害ガスが多くなる。(2)芳香族が多いと, ススが多く発 生し, 将来装着が予想される触媒コンバーターの触媒 を劣化させ，大気污染を助長させるなどの理由からで あつた。石油精製業界は, 鉛を除いた他に, 菏酷なガ ソリン組成の規制が行なわれるようなことになると， 実際問題，無鉛化をはかることは困難なので，反対の 立場をとつてきた。その後, 産構審の答申の中で『カ ソリン組成については芳香族, オレフィンなどの増加 を極力抑える方向で今後自動車排出ガス総合対策の進
展に応じて，具体的に対処していく。そして工業技術 院自動車安全公害研究センターの参画のもとに, 自動 車, 石油両業界の協力により一両年中に (1)芳香族, オレフィン 添加剂など燃料組成の浄化装置の性能に およぼす影響 (2)芳香族 オレフィンなど燃料組成の 排出ガス対策上の最適条件の解明，について実験研究 を実施のうえ，解決の具体策を得る必要がある』とい うことがうちだされ，ガソリン組成の問題は将来に残 されたかたちになつている。

ガソリン中の芳香族含有量が，極端に高い場合，無 鉛カソリンにおいては，オクタン価要求值が上昇する 傾向にあり，またランブリング現象を起こすことが考 えられる。一方オレフィン含有量が高い場合には，モ 一ター法オクタン価が低下するので, ガソリンの組成 は品質設計上からもある程度制約をうけることにな る。しかし今後の研究結果, あるいは現在予想もでき ないなんらかの理由で, 芳香族や, オレフィンの苛酷 な規制が行なわれるようなことになると，重大な問題 を提起することになる。表 5 はおもなガソリン基材性 状の一例を表示したものである。わが国のプレミアム ガソリンの製造方法は，各社まちまちではあるが，直 留ガソリンと改質ガソリン, 接触分解ガソリンと改質 ガソリンによる方法がもつとも一般的である。しかし 無鉛化において, 直留ガソリンと改質ガソリンでプソ ミアムガソリンを製造する場合, 直留ガソリンのオク タン価があまりに低く産構審の答申で示された最低オ クタン価レベルである95を目的としても，直留ガソリ

\section{表 5 高オクタン価ガソリン基材の性状}

\begin{tabular}{|c|c|c|c|c|c|c|c|}
\hline & $\begin{array}{l}\text { 95RON } \\
\text { 改質ガソ } \\
\text { リン }\end{array}$ & $\begin{array}{l}\text { 97RON } \\
\text { 改質ガソ } \\
\text { リン }\end{array}$ & $\begin{array}{l}\text { 接触分解 } \\
\text { ガソリン }\end{array}$ & $\begin{array}{l}\text { 俥質接触 } \\
\text { 分解ガソ } \\
\text { リン }\end{array}$ & 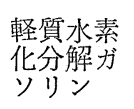 & $\begin{array}{l}\mathrm{C}_{5} / \mathrm{C}_{6} \text { 異性 } \\
\text { 化カリリン }\end{array}$ & $\mathrm{C}_{5}$ アルキレー \\
\hline $15 / 4^{\circ} \mathrm{C}$ & 0.7848 & 0.7957 & 0.7398 & 0.6746 & 0.6612 & 0.6575 & \\
\hline 蒸気圧 $\left(100^{\circ} \mathrm{F}\right) \mathrm{kg} / \mathrm{cm}^{2}$ & 0.315 & 0.290 & 0.450 & 0.830 & & 0.800 & \\
\hline $\mathrm{IBP}^{\circ} \mathrm{C}$ & 46.0 & 47.0 & 43.0 & 36.0 & 32.0 & 32.5 & 70.0 \\
\hline (エングラー） $10 \%$ & 74.5 & 77.0 & 60.0 & 49.5 & 40.5 & 39.0 & 91.5 \\
\hline $30 \%$ & 97.5 & 100.0 & 74.0 & 47.5 & 46.0 & 42.5 & 98.0 \\
\hline $50 \%$ & 116.5 & 123.0 & 97.5 & 55.0 & 52.0 & 46.0 & 101.5 \\
\hline $90 \%$ & 148.0 & 153.5 & 164.0 & 73.0 & 71.0 & 59.5 & 117.5 \\
\hline E P & 176.0 & 178.5 & 184.0 & 86.5 & 82.0 & 77.0 & 192.5 \\
\hline 組 成 飽 和 & 46.0 & 39.5 & 30.0 & 36.0 & 99.0 & 100.0 & 100.0 \\
\hline (FIA) オレフイン & 0.0 & 0.0 & 49.0 & 63.5 & 0.0 & 0.0 & 0.0 \\
\hline 芳 香 族 & 54.0 & 60.5 & 21.0 & 1.0 & 1.0 & 0.0 & 0.0 \\
\hline リサーチオクタン価(F-1) & 94.7 & 97.4 & 93.2 & 95.0 & 85.0 & 88.0 & 96.0 \\
\hline モーターオクタン価( F-2) & 82.8 & 84.7 & 78.7 & 79.0 & 81.0 & 86.0 & 94.0 \\
\hline センシティビティー & 11.9 & 12.7 & 14.5 & 16.0 & 4.0 & 2.0 & 2.0 \\
\hline
\end{tabular}




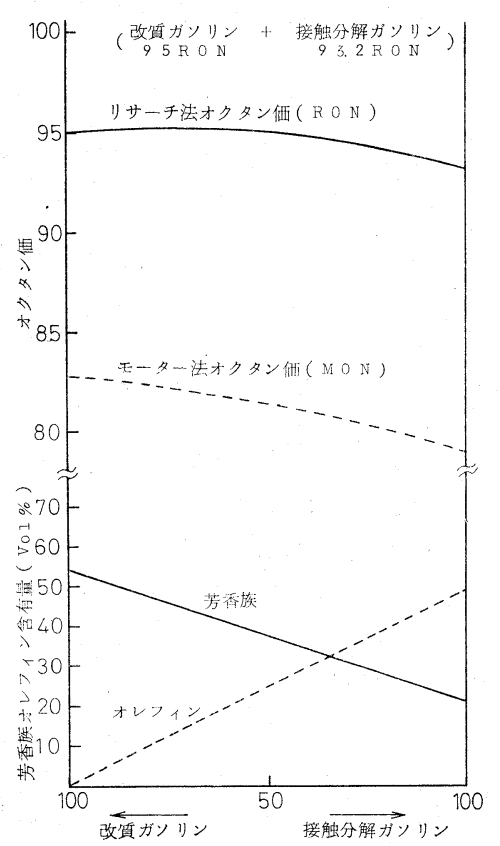

図 4 ガソリン基材の配合と組成変化 (1)

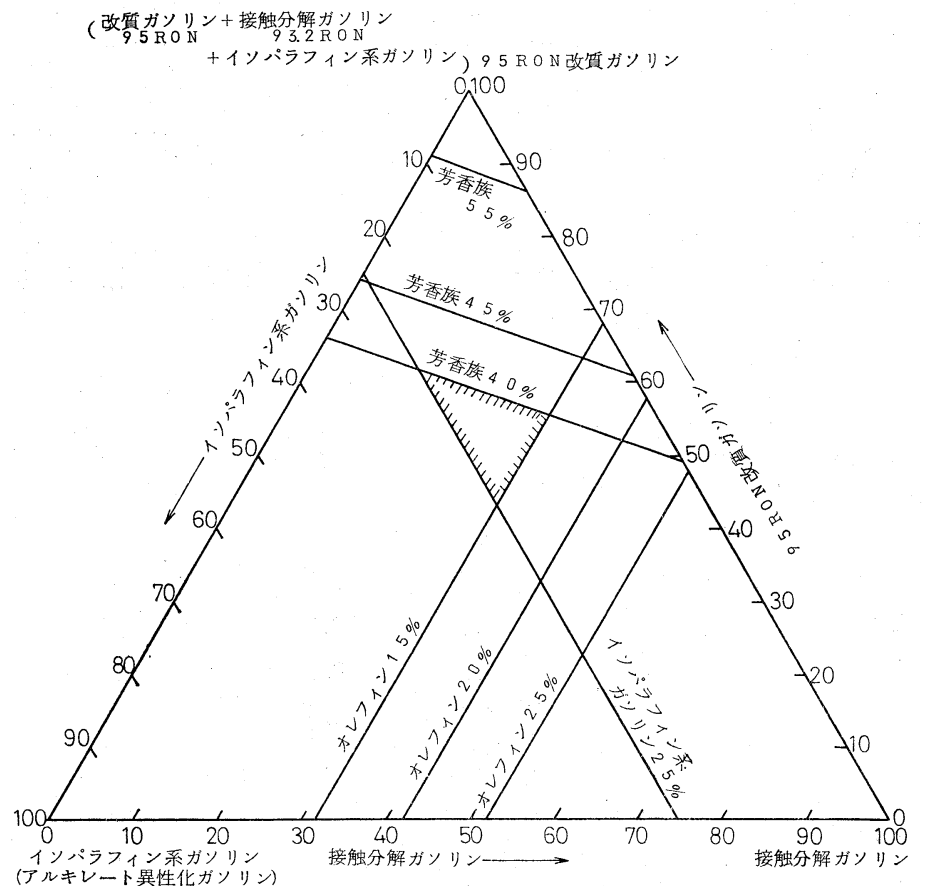

図 5 ガソリン基材の配合と組成変化（2）

ンの混合が抑えられ芳香族含有量は極端に高いものに なる。接触分解ガソリンと, 改質ガソリンとでプレミ アムガソリンを製造する場合のオクタン価および組成 の変化の一例を図 4 に表示する。オクタン価95の改質
ガソリンの配合比率を約 50\% 以上に保つことによつ て，リサーチ法オクタン価95のガソリンが得られる。 しかし組成的にみると，芳香族を低く抑えるとオレフ インが増加し，オレフインを抑えると芳香族がふえる という問題が生じる。したがつて，たとえば芳香族 40 \%以下，オレフィン15\%以下に抑えることは，この方 法では不可能である。そこで，このような組成上の制 限がある場合には，アルキレート，異性化ガソリン軽 質水素化分解ガソリンなどのイソパラフィン系のガソ リンの配合が必要となる。図 5 は 97RON 改質ガソリ ンと接触分解ガソリンに，イソパラフィン系ガソリン を配合した場合のガソリン配合比率と組成との関係の 一例を表示したものである。イソパラフィン系ガソリ ン基材は，その品質特性から，その配合比率は25\%以 下に限定されると考えられるので，図 5 のハッチング で示した領域に限定され，単に製造コストアップとい う問題以外に，実生産上，非常に許容範囲が狭くなる といつた問題も生じてくる。

1-3ガソリン製造装置の選定など

当然のことながら無鉛化に伴つて，ガソリンプール オクタン価をひきあげる必要が生じ る。しかしガソリン組成の問題や車 のオクタン価要求值などが明らかで ない現在，いかなる方法でこれに対 処するか, 加えて各石油会社の販売 政策や，各製油所によつて事情が千 差万別であり， 1 概に論ずることは できない。しかし，無鉛化に伴つ て, クリアオクタンバーレル (単味 オクタン価とガソリン量の積) がよ り必要になることは明らかで，各製 油所ともガソリン製造装置 (オクタ ンブースター）を新造設したり，既 存オクタンブースターの運転変更な どの努力が行なわれることになる。 まずオクタンブースターを選定する にあたつて，いろいろな問題が生ず ることになる。

1-3-1 ガソリン製造装置 ${ }^{899}$ の選定 ガソリン製造装置の代表的なもの として, 改質装置, 接触分解装置, アルキレーション 装置, 異性化装置, モソキュラシーブ装置, 水素化分 解装置などがあげられる。しかし，いざこれらのプロ セスのうちで，どれを採用するかとなると，原料事 情, プロセスの経済性, ガソリン特性, 既存ガソリン 
製造装置との関係など，いろいろな問題が発生するこ とになる。

(a)改質装置

改質装置は原料ナフサの入手の容易さ, 製造コスト が低廉であること，オクタン価が非常に高いなどの理 由で，わが国に限らず製油所には必須のガソリン製造 装置として建てられ，ガソリン基材の主役を果して きた。これはここ数年 $\mathrm{Pt}-\mathrm{Re}$ 二元金属触媒の開発な ぞ1011112)によって技術が著しく進歩し，無鉛化時代に おいても，一層重要性か增してくると思われる。しか し他にガソリン製造装置を持たない製油所において は, 改質カソリンの品質特性から今後要求されるプレ ミアム級ガソリンの品質動向いかんによっては, 改質 装置を新設するだけでは適正なカリリンをつくれない という事態が生ずる恐れがある。

\section{(b)接触分解装置}

アメリカに比べわが国の場合, 接触分解装置能力は 小さい。しかし現在接触分解装置を有しない製油所は もとより，改質装置原料ナフサに余裕のない製油所は 有力な無鉛対策プロセスとして採用するものと考えら る。しかし接触分解装置は, 一般に減圧重質軽油を 原料とするので, アスファルトの処理の問題が重油の 低イオウ化の問題と関連して発生する。先の他接触力 ソリンの $50 \%$ はオレフィンなので, オレフィン規制の 進展いかんによっては, これもプロセス選定のブレ一 キーの一因となろう。

(c)アルキレーション装置

アルキレーションには, 原料オレフィンによって, $\mathrm{C}_{2}$ アルキレート ${ }^{13)}, \mathrm{C}_{3}$ アルキレート, $\mathrm{C}_{3} / \mathrm{C}_{4}$ アルキレ 一ト， $\mathrm{C}_{4}$ アルキレート， $\mathrm{C}_{5}$ アルキレートなどがあるが そのうちで $\mathrm{C}_{3} / \mathrm{C}_{4}$ アルキレート， $\mathrm{C}_{4}$ アルキレートが一 般的である。アルキレートは無鉛化に伴い, 加鉛効果 がきわめて優れているという特徵は失われるが, 走行 オクタン価を上げるには依然として優れた基材であ り，何といってもガソリン組成の規制が行なわれるよ うなことになれば, 有力なガソリン組成調整基材とな りうる。しかしわが国の場合，原料ガスを確保するの が困難であるばかりか，製造コストが他のガソリン製 造装置と比へて断然高いという大きな欠点がある。そ の他触媒として, 硫酸やフッ化水素が使用されるの で，スラッジの処理の問題や毒性の問題があり,これ もまたアルキレーション装置がわが国において, 今後 とも期待できない理由となろう。

\section{(d)異性化装置}

異性化装置は，いままでガソリンのオクタン価がそ
れほど高くないこと，オクタン価上昇コスト(円 $/ \mathrm{k} l$ オ クタン価）が比較的高いこと，また異性化ガソリンを 配合した場合，ガソリンの低沸点留分のオクタン価が 高くなる利点を有しているが，これはある程度加鉛に よつてカバーできたなどの理由からそれほぼ問題にさ れなかつたプロセスであった。しかし近年，技術が著

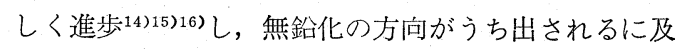
んでににわかクローズアップされてきた。とくに製 油所構造がわが国に類似して, ガソリンの生産比率が 低く，主として改質ガソリンと直留ガリリンの配合に よつて,ガソリンを製造しているヨーロッパでその傾 向が強い。分解装置を多く持ち, 低沸点留分のオクタ ン価上昇について, 比較的問題の少ないアメリカにお いても, 将来のガソリンプールオクタン価のレベルい かんによつては, 異性化装置は経済的であるという意 見が多くなつている。運転方法や，原料油性状にもよ るが, $\mathrm{C}_{5} / \mathrm{C}_{6}$ 異性化カリリンのリサーチ法オクタン価 は, 82〜92（モーター法オクタン価は80〜90）といわ れているが，実生産上での経済的なオクタン価は，90 RON が最大と考えられる。97RON の改質ガソリンに 88RON 異性化ガソリンを約 20\%配合することによつ て, 比較的揮発性のよい 95RON プレミアムガソリン が製造できる。異性化装置は接触分解ガソリンのよう に低沸点留分のオクタン価が高いガソリン基材を持た ない製油所において，将来プレミアムガソリン製造用 プロセスとして再評価されるであろう。しかし $C_{5} / C_{6}$ 異性化装置の原料油は需要の多い石油化学用ナフサで あることから, 原料確保の問題, またオクタン洒のレ ベルによつて, 配合量に制限をうけること, 加えて製 造コストが高いなどの問題があり選定にあたつては慎 重に検討されるべきであろう。

この他, 最近東亜石油や富士石油などが採用したモ レキュラーシーブ装置も無鉛ガソリン製造用プロセス として対象になる。原料およびガソリンの品質上の問 題は, $\mathrm{C}_{5} / \mathrm{C}_{6}$ 異性化ガソリンの場合とほぼ同じシチュ エーションにあるが，原料に対して約50\%副生される オクタン価の低いルマルパラフィンの評価いかんに よつて, 长の経済性は左右される。ノルマルペンタ ン，ノルマルヘキサン, ノルマルヘプタンなどは主と して抽出溶㓮, 重合溶媒などにその用途があるが, わ が国においては，上記の 2 装置が建設されたことによ つて，すでに供給能力が過剩になつている。したがつ て将来モレキュラーシーグ装置は単独で建設されると いうより，むしろ異性化装置とのコンビネーションで 使用されることになると考えられる。

無鉛の場合プロセスを建設するにあたつて，装置能 
力と稼動率の関係がいままでにもまして重要になつて くる。一般に新装置を建設する場合, 各社によつてま ちまちではあるが，余裕を持たせて建設され，フル稼 動後に拉けるオクタンバーレルの需要の增加に対して は，ある程度加鉛量を增やすことによつて，オクタン バーレルの不足に対処できた。しかし無鉛化になる そ，この操作ができなくなる。したがつて，当初稼動 率の低い装置を建てる必要が生ずる。化学製品と異な り，精製コストのうちで間接費の占める割合が大きい 石油精製にとつて, これは無視できない問題であり, 加鉛時代にまして的確な品質および需給計画が必要と なる。同時に，グルーブ間の共同投資の問題なぞも含 めて，ガソリン製造装置の建設のあり方が再検討され てくるものと考えられる。

\section{1-3-2 既存カソリン製造装置}

ガソリンの無鈶化に伴つて, 製油所用地の問題など から, 装置のエキスパンションができない製油所はも ちろんのこと, 各製油所とも総合的な経済性に立脚し て，オクタンバーレルをひき上げたり，とくにプレミ アムガソリン製造用として，高オクタンガソリン基材 を得るための必要性が増してくる。その一例として, 改質装置においては, 原料油の変更, 新しく開発され た触媒の使用, 運転苛酷度の上昇, また改質ガソリン の再分留 (スプリッティング) などがあげられる。接 触分解装置においても同じことで，コンバージョンの 上昇, 原料油の改善, ガソリン得率の高いゼオライト 系触媒の使用, 接触分解ガソリンの再分留 (スプリッ ティング）また分解カリリンの中間留分を改質装置に かけ，オクタン価をひきあげることなども検討の対象 になろう。しかし一般にガソリンのオクタン価をひき 上げると，得率が低下寸るので，オクタン価とガソリ ン量の積として定義されるオクタンバーレルの增加 は，その程期待できない。いうまでもなく，ガりリン のスプリッティングは特別なガソリン基材を得るには 有力な手段であるが，全体のオクタン価をひさ上げる 方法ではない。したがつて, 既存設備ではオクタンバ ーレルのひきあげには限界があり，ガソリン製造装置 の新設や他からガソリン基材を手当する必要が生じ る。これは転送コストの著しい增加を意味するもので あり, 各社にとつて重要な問題となろう。

\section{1-4 無鉿化に伴うコストアップ}

無鉛化に伴う製造コストアップの問題については, アメリカにおいては, いろいろなデータが発表され， 全米平均的にみてそのコストアップは， $2.2 \varnothing /$ gal., 4.1ф/gal., $0.9 \varnothing / \mathrm{gal}$ と，その数值はまちまちであ
る17)。しかし，これらの結果は，アメリカにおける需 給パターン，品質㧍よび価格をもとに試算されたもの で，事情のまつたく異なるわが国にとつては単なる参 考程度にしかすぎない。わが国の場合, 全国的にみ て，はたしてどの程度コストアップになるのかまだ試 算された例がなく見当がつかない状態である。

\section{表 6 主要ガソリン製造プロセス}

\begin{tabular}{|c|c|c|c|c|}
\hline 装置名 & $\begin{array}{l}\text { 置能刀 } \\
\text { BPSD) }\end{array}$ & $\begin{array}{l}\text { 建設費 } \\
\text { (億而) }\end{array}$ & 原料油 & $\begin{array}{l}\text { ガソリン } \\
\text { 収率(\%) }\end{array}$ \\
\hline 接解分解 & $\left\{\begin{array}{l}10,000 \\
20,000\end{array}\right.$ & $\left.\begin{array}{l}27 \\
35\end{array}\right\}$ & 重質軽油 & $50-55$ \\
\hline 水素化分解 & $\left\{\begin{array}{r}5,000 \\
10,000\end{array}\right.$ & $\left.\begin{array}{l}17 \\
28\end{array}\right\}$ & 重質軽油 & 35 \\
\hline アルキレーション & $\left\{\begin{array}{l}2,000 \\
3,000\end{array}\right.$ & $\left.\begin{array}{r}8 \\
11\end{array}\right\}$ & イ゙チレン & 50 \\
\hline 接触改質 & $\left\{\begin{array}{l}10,000 \\
20,000\end{array}\right.$ & $\left.\begin{array}{l}23 \\
30\end{array}\right\}$ & 重質ナフサ & $70-80$ \\
\hline 異性化 & $\left\{\begin{array}{l}3,000 \\
5,000\end{array}\right.$ & $\left.\begin{array}{r}8 \\
11\end{array}\right\}$ & 軽質ナフサ & 98 \\
\hline モレキュラシープ & $\left\{\begin{array}{l}3,000 \\
5,000\end{array}\right.$ & $\left.\begin{array}{l}6 \\
8\end{array}\right\}$ & 軽質ナフサ & 50 \\
\hline
\end{tabular}

表 6 は無鉛化に伴つて建設されると思われる主要カ ソリン製造装置の建設費を表示したものである。無鉛 化の製造コストアップは, 品質上の要求, とくにオク タン価のレベル, ガソリン組成の規制の有無, またそ の程度によつて非常に変動する。無鉿化の開始時点 で, 品質上の要求がそれ程苛酷でない場合でも, 追加 設備投資だけで数百億円以上になるだろうと考えられ る。加えて, 各製油所に平均的に小規模のガソリン製 造装置を建設することは, 建設用地, 原料油調達上の 制限, プロセスの経済性の面から不可能であり, 製油 所間のガソリン基材の転送量が増加する。この輸送面 でのコストアップは, 製造コストアップの問題ととも に，石油精製業界にとつて大きな問題となるであろ う。わが国においても今後, 低圧縮比で設計されるも のと考えられるが, 加給ガソリン時代と異なり, オク タン価要求值のわずかの上昇も製造コストの加速度的 な上昇を招くことになる。したがつて国民経済的な立 場に立つてエンジン設計が行なわれることがますます 重要になつてくることは当然であろう。

\section{2 無鉛ガソリン使用上の問題点}

無鉛化に入つて, 新車は無鉛ガソリンに対処しうる としても, 図6で示すように無鉛化がスタートする昭 和 49 年には，一千万台以上も走行しているものと推定 される未対策車が無鉛ガソリンを使用することによつ ていろいろな問題が発生するものと考えられている。 


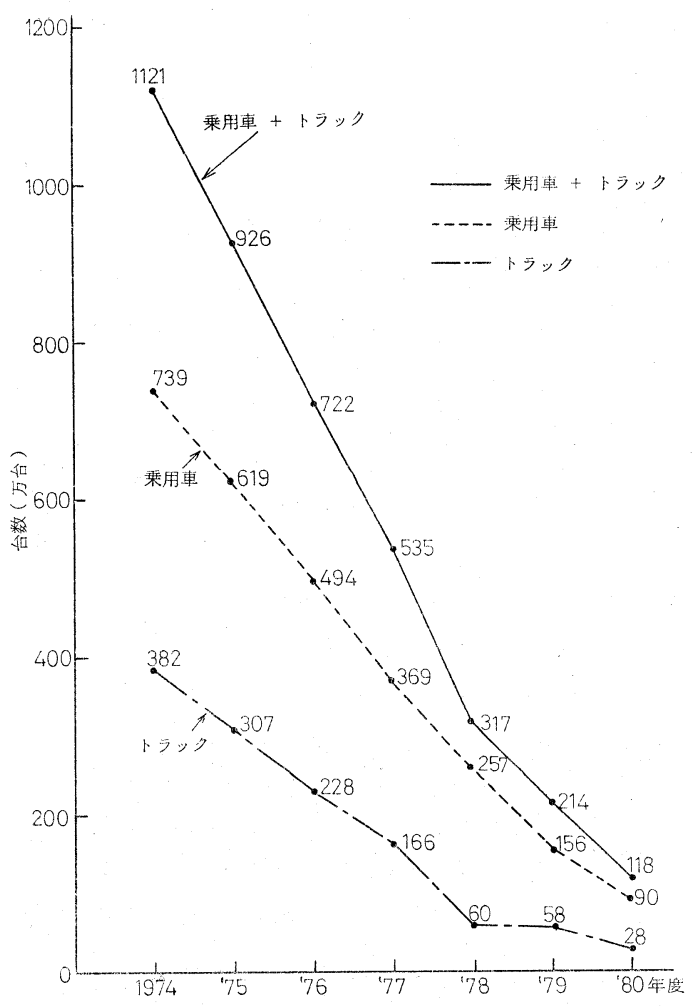

図 6 わが国における未対策車残存台数 (自動車工業会の推定值)

中でもバルブシートリセッションと，オクタン価低下 によるノッキング（充足率の低下）が大さな問題とな ろう。

2-1 未対策車のバルブシートリセッション

バルブシートリセッションの現象やそのメカニズム については, D.O.Neill18), W.S. Giles ${ }^{19)}$, Douglas Godfrey and Richard Courtney 20 ) が報告している が，バルブリセッションとは無鉛ガソリンを使用した 場合，排気バルブは高温にさらされるので，弁と弁座

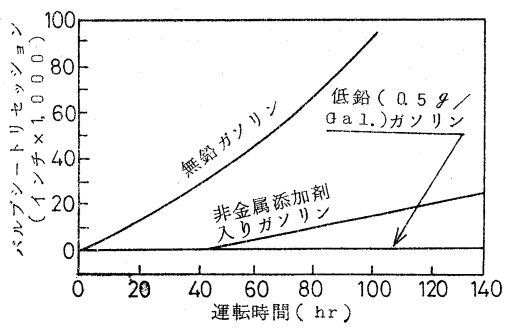

図 7 バルブシートセッションに対する鉛添 加剤の効果 (Esso社データ)
の間に溶融現象が起こり，損傷することである。加鉛 ガソリンの場合には，鉛化合物が表面に付着して，こ の現象を防ぎえたが，無鈶カソリンでは，防ぎえなく なる。その対策としてガソリンや潤滑油の添加剤によ つて，解決でさないかという期待もあつたが，ガソリ ンエンジンの場合, 燃焼温度が高いので, 有効なバル ブシートリセッション防止剤は今のところ見当らず, 金属材料の改善によつて解決される方向にある。一時 リン化合物が，バルブシートリセッションの防止に效 力があるとして注目されたが図 7 に示すように，それ 程顕著なものではない。リン化合物は, 触媒マフラー の触媒に対して鉛以上に有害であるといわれており， 一般に根本的解決策にならないと思われている。さて 新車に対しては，バルブシートリセッション防止対策 が施されるので，問題になるのは未対策既販車であ る。バルブシートリセッションは, 高速, 高負荷運転 など起こりやすく，したがつて小型トラックの方が乗 用車より発生率が高くなる。バルブシートリセッショ ンが起こると馬力の低下，燃費の増加，および排気カ スの増加をもたらし，ひどい場合には走行すら困難に なるといわれている。その対策として，バルブシート リングの搟入などが考えられているが, エンジン構造 上，またタイミング的にもすべてこの方法で解決する のは困難であるとされている。そこで未対策車用とし て，低鉛ガソリンを残すべきだという意見もある。し かしこれはマケットの面で新たに大きな問題をひきお こすことになる。たとえ，過渡的な現象とはいえ，無 鉛化がかえつて大気活染を助長したり，運転の安全性 を脅かすことは好ましいことではなく，総合的見地に 立つて早急なる解決策が望まれるわけである。

\section{2-2 既販車のノッキング（充足率の低下）}

1969年型国産車で 1, 000cc 以上の排気量を有する車 の充足率は，97オクタン価で約85～95\%である。既販 車に対する充足率は無鉛化の時点でもそれほど変わる とは思われないので，無鉛化に伴い95RON にオクタ ン価が低下したとすると, 既販車のノッキングが問題 になることが当然予想される。もちろんその場合, 点 火時期の調整などによつて, 幾分カバーできるが, 無 鈶ガソリンによるオクタン価要求值の上昇分がマイナ ス要因として相殺してしまうことも考えられる。この 問題については，無鉛カソリンのオクタン価をひき上 げる以外に策がないが，無鉛で現行程度のオクタン価 を有するガソリンを製造することは非常に困難であ り，いまのところ具体的な解決策を見出せない状態に ある。 
お わりに

無鉛化に伴つて，わが国石油精製業界は技術的にも 経済的にも多大な影響をうけることはいうまでもな い。

さらにガソリンの無鉛化は，バルブシートリセッシ ヨンなどの新たな問題を提起し, 問題を一層複雑化し ている。しかし自動車による大気污染は， $\mathrm{SO}_{2}$ 大気污 染の問題とならんで重大な社会問題となつており，今 後工業が発達し，国民の生活水準が上がるにつれて， きれいな空気，澄みきつた青空を求める要望は，ます ます高まるであろう。その要望に答えるためにも，一 企業，一業界の利益にこだわることなく官民一体とな つた総合的な対策が必要であり需要家の全面的な協力 があつてこそこの目的が達せられよう。

$$
\text { 文献 }
$$

1) 島村ら，「自動車排ガス公害」

2) E. J.Forster et al., "Effects of leaded versus unleaded gasolines on stabilized octane requirements" presented at the National Fuels and Lubricants Meeting, September 10-11, 1970 New York City

3) L. O. Stine et al., Oil \& Gas J., 67, May31, 49 (1971)

4) J.E. Riegel, "Automobiles : The important variable affecting road-laboratory octane correlation equations" presented at the 35 th Midyear meeting of the API's Division of Refining, Houston, May 14, 1970

5) A.E. Felt et al., Automobile Eng. Mar., 54 (1971)

6) J.C.Dumyer et al., Hydrocarbon Processing May, 111 (1971)

7) B.W. Struth et al., The impact of new gasoline specification on refineries of the future, presented at A. I. Ch. E. Meeting Houston-1971

8) "1970 Refining Processes Handbook", Hydrocarbon Processing, Sept. 163 (1970)

9) 石油学会編「石油精製プロセス」
10) J. A. Nevison et al, "Catalytic reforming advances with E-501 Catalyst" presented at a Session on Process Improvement During the 35 th Midyear Meeting of the API's Division of Refining, Houston, May 13, 1970

11) G. D. Gould et al., Oil \& Gas J., Nov. 30, (1970)

12) E. A.Sutton, "Recent development in Platforming" Presented at UOP 1971 Technical Seminar "Modern trends in refining"

13) R.L.Dickenson et al., Oil \& Gas J., May 17, 120 (1971)

14) L. J. Laplante "Economics of Conbining $n$-Paraffin Separation with Isomerization and Distillation for Various Stocks in the $\mathrm{C}_{5} / \mathrm{C}_{6}$ Range" presented at the NPRA Annual Meeting Mar. 21-23, 1971 San Francisco, California

15) A. H. Richardson "Isomerisation in refineries faced with a demand for low-lead, no-lead gasoline" presented at the NPRA Annual Meeting Mar. 21-23, 1971 San Francisco, California

16) G.F. Asselin, "UOP PENEX PROCESS FOR $\mathrm{C}_{5} / \mathrm{C}_{6}$ ISOMERIZATION" Presented at the Isomerization Symposium of the JPI TOKYO, Japan Sept. 14, 1971

17) 石油政策, 1970年 5 月 20 号

18) DO'Neill et al., Journal Automotive Eng., 78, (8), Aug. 17-26 (1970)

19) W.S. Giles "Valve Problems with Lead-Free Gasolines", SAE Mississippi Valley Section, Oct., 1970

20) Douglas Godfrey and Richard Courtney, "Investigation of the Mechanism of Exhaust VaIve Seat Wear in Engines Run on Unleaded Gasoline”, Paper No.710356, SAE Automotive Engineering Congress, Detroit, January 1971 


\title{
Unleaded Gasoline Problems
}

\author{
by Sanichiro Uchida
}

(Maruzen Oil Co., Ltd.)

\begin{abstract}
SYNOPSIS-In Japan all the lead additives in both premium and regular gasolines are to be removed from April 1, 1974. This project not only has a great influence on our refineries technically and economically, but also poses many problems on manufacturing and using thereof. As far as the former is concerned, it includes such problems as how to manufacture the well balanced unleaded gasoline, in connection with this, the restriction of gasoline composition, how to select the suitable octanebooster, and manufacturing cost up. The latter includes valve sheet recession and knocking troubles of the older cars without new devices. Here, the author briefly discusses these problems.
\end{abstract}

